\title{
TAXANES IN ADJUVANT BREAST CANCER TREATMENT
}

\author{
ANA TEČIĆ VUGER ${ }^{1}$, MIRJANA PAVLOVIĆ ${ }^{1}$, NIKOLINA LONJAK ${ }^{1}$, MILENA GNJIDIĆ ${ }^{2}$ \\ LJUBICA VAZDAR ${ }^{1}$, VESNA PAVLICA ${ }^{3}$, ROBERT ŠEPAROVIĆ ${ }^{1}$ \\ ${ }^{1}$ Department of Radiotherapy and Medical Oncology , University Hospital for Tumors, \\ Sestre milosrdnice University Hospital Center, Zagreb \\ ${ }^{2}$ Department of Oncology, Division of Medical Oncology, University Hospital Center Zagreb, Croatia \\ ${ }^{3}$ Hospital Pharmacy, University Hospital for Tumors, Sestre milosrdnice University Hospital Center, \\ Zagreb
}

\begin{abstract}
Taxanes are irreplaceble drugs in treatment of many solid malignancies. In breast cancer they represent the backbone of adjuvant therapy and are important option in treatment of advanced and metastatic disease. Since their discovery in 1960 's they went through a long journey of clinical development and positioning in clinical practise of treatment of early breast cancer. Taxanes belong to the fourth group of cytotoxic drugs, which act as mytotic inhibitors, causing the death of the cell in metaphase. Clinical trials conducted in patients with breast cancer evaluated different combinations of other chemotherapeutics with taxanes, different modes of administration, effectiveness of different chemotherapy regimens including taxanes in different subtypes and stages of the disease and effectiveness of individual taxanes in comparison with one another. Based on the results of those trials, today the relevant global oncology associations reccomend the use of taxanes in treatment of early breast cancer, pointing out their significant benefit in total reduction of breast cancer mortality and risk of disease reccurence by $20-30 \%$ comparing to anthracycline only protocols. The purpose of this literature review was to provide comprehensive information about development of taxanes and their position in routine everyday clinical practise.
\end{abstract}

KEY WORDS: taxanes, mytotic inhibitors, cytotoxic drugs, chemotherapy regimens, early breast cancer

\section{Sažetak}

TAKSANI U LIJEČENJU RANOG RAKA DOJKE

Taksani su nezamjenjivi lijekovi u liječenju mnogih solidnih tumora. U karcinomu dojke predstavljaju okosnicu adjuvantne terapije i važna su opcija u liječenju uznapredovale i metastatske bolesti. Od njihovog otkrića 1960-ih prošli su dugi put kliničkog razvoja i pozicioniranja u kliničkoj praksi liječenja ranog raka dojke. Taksani pripadaju četvrtoj skupini citotoksičnih lijekova koji djeluju kao inhibitori mitoze, koji uzrokuju smrt stanice u metafazi. Klinička istraživanja provedena na bolesnicama s karcinomom dojke procjenjivala su različite kombinacije drugih kemoterapeutika s taksanima, različite načine primjene, djelotvornost različitih kemoterapijskih protokola koji uključuju taksane u različitim podtipovima i stadijima bolesti te učinkovitosti pojedinih taksana u usporedbi s drugim. Na temelju rezultata tih pokusa, danas relevantne globalne onkološke udruge preporučuju uporabu taksana u liječenju ranog raka dojke, pokazujući njihovu značajnu korist u ukupnom smanjenju rizika od smrti i povrata bolesti za 20-30\% u odnosu na protokole bazirane samo na antraciklinu. . Svrha ovog pregleda literature je pružanje sveobuhvatne informacije o razvoju taksana i njihove pozicije u rutinskoj svakodnevnoj kliničkoj praksi.

KLJUČNE RIJEČI: taksani, mitotički inhibitori, citotoksični lijekovi, kemoterapijski režimi, rani rak dojke 


\section{INTRODUCTION}

Various forms of systemic antineoplastic treatment are used in the adjuvant treatment of early breast cancer: chemotherapy, endocrine therapy and targeted therapy, depending on the stage of the disease, biological characteristics of the tumor, as well as the characteristics of the patient himself. The decision on the optimal form of systemic antineoplastic treatment is made by a multidisciplinary team. The backbone of adjuvant chemotherapy in the treatment of early and advanced non-metastatic breast cancer consists of two groups of cytotoxic drugs, anthracyclines and taxanes. Oxford metaanalysis from 2005 (EBCTCG - Early Breast Cancer Trialists' Collaborative Group), which included 194 studies with more than 145000 patients, showed that by using anthracycline-containing adjuvant polychemotherapy, the risk of mortality decreased by $38 \%$ in patients under the age of 50 and by $20 \%$ in the group from 50 to 69 years of age, which clearly confirmed the position of anthracyclines as the gold standard in adjuvant treatment of breast cancer in patients under 70 (1).

However, anthracycline efficacy in treating cancer is limited by a cumulative dose-dependent cardiotoxicity (recommended cumulative maximum of doxorubicin is $450 \mathrm{mg} / \mathrm{m} 2$ ), which can cause irreversible heart failure. The cardiotoxicity is mediated by cellular mechanisms, responsible for increased apoptosis in cardiac myocytes. This can cause irreversible structural changes which is especially important to keep in mind when treating population of potentialy curable patients so patients should be closely monitored during the adjuvant treatment. This problem was one of the reasons investigators push forward to find another drug alternative in this setting (2).

Taxanes have been known since the 1960's, after paclitaxel was isolated from pacific yew as a part of the NCI (National Cancer Institute) experiment, which examined the characteristics of a large number of different trees. Given the non-viability of raw material consumption, relative to the amount of compound obtained, a semi-synthetic method of obtaining paclitaxel was developed. The clinical course of drug development was slow. In 1987 paclitaxel was introduced to treat ovarian cancer, breast and lung tumors. In the 1980's docetaxel was synthesised and it has been used in breast cancer therapy since the 1990's (3).
Taxanes belong to the fourth group of cytotoxic drugs, which act as mitotic inhibitors. They are inhibitors of mitosis of the spindle fibers in the cell and cause a 'mitotic block' at the transition from metaphase to anaphase of the cell cycle. They are responsible for binding to microtubules, resistance to depolymerization of the resulting polymers, generation of defective microtubules and the death of the cell in metaphase. Comparison of taxanes showed that docetaxel has a higher affinity for microtubules, achieves better transplantation in the cell, has slower release from the tumor cell, induces polymerization stronger and is more potent than paclitaxel. It has 12 times stronger cytotoxic activity than paclitaxel. In preclinical studies, docetaxel showed widespread activity in the cell cycle $(4,5)$.

The most pronounced side-effect of taxanes therapy noted in clinical studies and in clinical practise is neutropenia which can reach high grade in up to $80 \%$ of patients treated with docetaxel and about $10 \%$ of patients developes febrile neutropenia (this effect is less common with paclitaxel and least common with nab-paclitaxel). Also important and dose limiting side-effect of therapy is periferal neuropathy which occures in high grade in about $10 \%$ of patients. Less frequent side-effects include anemia, vomiting, stomatitis and edema (6).

\section{Addition of taxanes improves results of adjuvant therapy}

Taxanes have been used in breast cancer therapy since the 1990s. Their activity was first tested in advanced disease studies and then in adjuvant use in early and advanced non-metastatic breast cancer. The American Food and Drug Administration (FDA) approved the use of paclitaxel in the treatment of metastatic breast cancer in 1994. Approval was obtained based on a phase III study which compared two doses of paclitaxel $\left(175 \mathrm{mg} / \mathrm{m}^{2}\right.$ and $135 \mathrm{mg} / \mathrm{m}^{2}$ every three weeks) in patients who did not respond to prior chemotherapy. It has been shown that higher doses of paclitaxel have achieved longer median time to progression of the disease (TTP), longer median overall survival (OS), and longer median survival over 6 months (7).

The development of targeted indications for the treatment of non-metastatic breast cancer with taxanes has begun with the first generation of randomized clinical trials investigating the addition 
Lib Oncol. 2018;46(1):29-35

Table 1.

FIRST GENERATION OF CLINICAL TRIALS WITH TAXANES

\begin{tabular}{|c|c|c|c|}
\hline Authors/Trial & No. of patients & Regimen & Results \\
\hline Henderson et al./CALGB 9344 & $3,121 \mathrm{pts}$ & AC (doxo 60/75/90 mg/m2) 3w +/- paclitaxel $175 \mathrm{mg} \mathrm{3w}$ & $\begin{array}{l}\text { DFS } 70 \% \text { vs. } 65 \% \\
\text { OS } 80 \% \text { vs. } 77 \%\end{array}$ \\
\hline Mamounas et al./NSABP B-28 & $3,060 \mathrm{pts}$ & AC vs. AC+paclitaxel & $\begin{array}{c}\text { DFS } 72 \% \text { vs. } 76 \% \\
\text { OS } 85 \% \text { vs. } 85 \%\end{array}$ \\
\hline Roche et al./PACS 01 & $1,999 \mathrm{pts}$ & FECx6 3w vs. FECx3+docetaxelx3 3w & $\begin{array}{c}\text { DFS } 73 \% \text { vs. } 78 \% \\
\text { OS } 87 \% \text { vs. } 91 \%\end{array}$ \\
\hline GEICAM 9906 & 1,246 pts & FECx6 3w vs. FECx4 3w+paclitaxelx8 1w & $\begin{array}{l}\text { DFS } 72 \% \text { vs. } 78 \% \\
\text { OS } 87 \% \text { vs. } 90 \%\end{array}$ \\
\hline BCIRG 001 & $1,491 \mathrm{pts}$ & FAC 6 6 3 vs. TAC 6 6w & $\begin{array}{l}\text { DFS } 68 \% \text { vs. } 75 \% \\
\text { OS } 81 \% \text { vs. } 87 \%\end{array}$ \\
\hline
\end{tabular}

of taxane to anthracyclines, compared with the use of anthracycline only protocols. A large study by Henderson and associates, CALGB (Cancer And Leukemia Group B) 9344, on over 3, 000 breast cancer patients, showed that the addition of paclitaxel to anthracycline protocol (to the current standard treatment protocol of $4 \times \mathrm{AC}$ ) provided a $17 \%$ reduction in the relative risk of disease recurrence, as well as $18 \%$ reduction in the relative risk of mortality. Clearly greater benefit has been shown in patients with hormone-independent disease. However, the CALGB 9344 study did not investigate the same duration of comparable chemotherapy protocols, so it positioned taxane chemotherapy as an alternative to prolonged anthracycline therapy (8). A very similar NSABP B-28 study by demonstrated that the addition of paclitaxel to anthracycline protocol significantly reduced the risk of recurrence, but did not prolong OS (90). According to a study PACS 01, by Roche et al., docetaxel administration after standard sixcycle FAC (5-fluorouracil, doxorubicin, cyclophosphamid) protocol, reduced risk of disease recurrence by $18 \%$, with a total of $27 \%$ reduction in the risk of death (10). The study GEICAM (Spanish cooperative breast cancer research group) 9906 showed $23 \%$ reduction in risk of disease recurrence with the use of weekly paclitaxel after FEC (5-fluorouracil, epirubicin, cyclophosphamid), compared to the use of anthracyclines only (11). Study by Buzdar et al. confirmed that improved results, obtained in previous adjuvant anthracycline plus taxane studies, were undoubtedly caused by addition of taxanes to chemotherapy protocol, rather than the longer duration of adjuvant therapy when adding taxane (12). (Table 1.)
Two studies have relativized the role of taxane therapy in the adjuvant breast cancer treatment. UK TACT and smaller Albert et al. study showed no significant difference between DFS and OS between group of patients treated with anthracycline-based polychemotherapy only and patients treated with antracycline plus taxane $(13,14)$.

\section{Concomitant use of taxanes and anthracyclines and taxanes without antracyclines}

Studies that investigated combination of taxanes with doxorubicin, are two major studies, BCIRG (Breast Cancer International Research Group) 001 and E 2197. In the first study, the comparison of anthracycline protocols FAC and TAC (docetaxel + doxorubicin + cyclophosphamide) resulted in $28 \%$ reduction in risk of disease recurrence and $30 \%$ reduction in risk of death with TAC chemotherapy (15). (Table 1.) The mentioned fiveyear follow-up results were maintained after 10 years of follow-up (16). TAC also showed advantage in DFS compared to FAC in high-risk patients without metastases in the lymph nodes (19). Study E 2197 demonstrated, on 2950 patients, after 53 months follow-up no statistically significant difference in DFS and OS between AT (doxorubicin + docetaxel) and AC (doxorubicin + cyclophosphamide) protocol, with both protocols showing unexpectedly good results, although doubtfully suboptimal dose of docetaxel was applied (17).

USO 9735 demonstrated the advantage of using taxanes without anthracyclines (comparison of TC to AC protocol). After seven years of followup, TC protocol showed the advantage in DFS and 
OS in both older and younger patients, and the advantage was more pronounced with longer follow-up, positioning the TC protocol as a standard of non-anthracycline protocols (18).

\section{Data from meta-analysis}

In order to determine the role of taxanes in adjuvant breast cancer treatment, Cochrane metaanalysis was performed on 21000 patients in 12 studies. The analysis included patients with operable disease, stage I - III. Use of taxanes provided statistically significant prolongation of disease-free survival (DFS) and overall survival (OS). However, subgroup of patients that would have the highest benefit of taxane therapy was not identified, so it is recommended that all patients with stage I disease should be considered for adjuvant therapy. In patients with lymph node involvement, adjuvant chemotherapy including taxanes showed a DFS prolongation of $24 \%$ and OS prolongation of $15 \%$, compared to adjuvant non-taxane treatment. Proportionally achieved risk reduction was the same in patients with and without lymph node involvement. The greatest benefit of chemotherapy has been shown in patients under the age of 50, and data were missing for those older than 70 years. This metaanalysis has lead to the conclusion that the addition of taxanes to adjuvant chemotherapy increases its effectiveness, regardless of age, nodal status, tumor size and stage, and hormone receptor expression. The preferred mode of administration is sequential over the concomitant (20).

In 2012, the data from the before mentioned EBCTCG metaanalysis from 2005 were updated. More than 40000 patients, treated with the protocol including taxanes, were involved in the study. The parameters that have influenced the reduction of recurrence and mortality risk were anew considered. In the context of taxane aplliance, the results showed that the use of taxanes in any combination gave better results than disuse and that prolonged treatment yielded better results compared to earlier interruption of therapy, but with the risk of cummulative toxicity, and polychemotherapy protocols yielded better results compared to monochemotherapy. Overall, adjuvant chemotherapy based on anthracyclines and taxanes has shown a $1 / 3$ reduction in breast cancer mortality compared to observation (21).

\section{Weekly paclitaxel - an option of choice}

The second generation of adjuvant randomized clinical trials compared different regimens using taxanes, the differences between sequential and concomitant (combination) use and the differences between dose dense and standard (threeweek) applications. The CALGB C9741 study compared, on 2000 patients, four paclitaxel regimens; standard sequential application after AC regimen and single sequentional $\mathrm{A}>\mathrm{P}>\mathrm{C}$ regimen in two-week (dose dense) or three-week intervals. After 36 months of monitoring, the two-week paclitaxel regimen showed a significant advantage in DFS and OS, but after 69 months, the difference in OS disappeared. There was no difference between the sequentional drug administration and the standard AC-taxane sequence (22). In the BIG 2-98 study, involving 2900 patients, the difference between sequential and concurrent administration of docetaxel with doxorubicin was investigated. The comparison showed the advantage of the sequence $\mathrm{A}>\mathrm{T}>\mathrm{CMF}$ in comparison to $\mathrm{A}>\mathrm{CMF}$, but the same advantage was not observed in AT> $\mathrm{CMF}$ when compared to $\mathrm{A}>\mathrm{CMF}$. After ten years of follow-up, the DFS was not significantly prolonged in the case of anthracycline-taxane sequence as it was in earlier follow-up, but docetaxel showed and maintained significant benefit in high-risk ER (estrogen receptors) dependent patients (23).

In the study by Shulman et al., comparing three protocols, AC> T, TAC and AT, the standard sequence $\mathrm{AC}>\mathrm{T}$ showed significantly better DFS than TAC and AT, but not significantly better OS. AT was shown not to be inferior to TAC, thus additionally narrowing the indication area for the highly toxic TAC protocol (24).

The comparison of taxane based chemotherapy was performed in a large study by Sparano et al., E 1199 which included 4954 breast cancer patients. Study compared paclitaxel and docetaxel in weekly verusus three-week regimen in sequential application after standard four-cycle anthracycline (AC) therapy. After 63,8 months of follow-up, the benefit of the weekly paclitaxel and three-week docetaxel over three-week paclitaxel, has been shown. Weekly paclitaxel showed an advantage in DFS and OS (docetaxel only in DFS), in patients with positive hormone receptors, as well as in Her2 negative patients. This made the paclitaxel weekly 
regimen an option of choice (25). The SWOG 221 study on 2700 patients showed, after six years of follow-up, that low dose weekly paclitaxel $(80 \mathrm{mg} /$ $\mathrm{m}^{2}$ for 12 weeks) was as effective as dose-dense paclitaxel $\left(175 \mathrm{mg} / \mathrm{m}^{2}\right.$ every two weeks, supported by granulocyte colonies growth factors) but significantly less toxic (26). A small stage II study of Burkard et al., compared standard docetaxel (4xTC every three weeks) with dose dense application (4xTC every two weeks), supported by granulocyte colonies growth factors. Both regimens have shown a similar profile of toxicity and tolerability (27). Further research results are expected. A study by a group of authors from Greece in 2014 showed similar results in DFS between dose dense administration of paclitaxel and docetaxel, following the anthracycline protocol (4xFEC) in patients with involved lymph nodes, but because of the more acceptable toxicity profile, paclitaxel has been confirmed as a taxane of choice (28).

\section{Taxanes in HER2 positive disease}

In HER2 positive breast cancer, which accounts for about $20 \%$ of all breast cancers, patients have greater risk of disease relaps and death from metastatic disease. In this subgroup of patients several studies have positioned taxanes as standard of treatment in combination with trastuzumab immunotherapy $(29,30,31)$. A small, uncontrolled single center study (the so-called APT study) by Tolaney et al., performed on 406 low-volume tumor patients without affected lymph nodes, showed $93.3 \%$ DFS and $95 \%$ OS after 7 years of follow-up, with the combination of weekly paclitaxel with trastuzumab followed by trastuzumab up to one year of therapy. This study has shown that, in localized small HER2 positive tumors, it is possible to avoid administration of anthracyclines in adjuvant treatment (32). Jones and colleagues study showed good results with four cycles of $\mathrm{TCH}$, followed by trastuzumab up to a total of one year of treatment in patients with lower risk disease (33) and Perez et al. demonstrated the advantage of concomitant application of trastuzumab with taxanes versus sequential treatment (34).

\section{DISCUSSION}

With the review of historical development of targeted indications for use of taxanes, as well as the positioning of these drugs in breast cancer treatment, several important points of reference were made. The major studies, such as the CALGB 9344, PACS 01 and BCIRG 001 set taxanes to the basis of adjuvant breast cancer therapy. Then there were studies which raised doubts about the advantage of introduction of taxanes with former anthracycline treatment standards and urged to seek additional confirmation through new research, such as the studies NCIC CTG MA 21.1 and the UK TACT. A series of meta-analysis clearly showed the benefit of introducing taxanes. Study E 1199 confirmed the importance of the mode and the regimen of administration itself and defined weekly paclitaxel and three-week docetaxel as the regimens of choice. There were no clear differences or advantages of one of the taxanes over the other. A TC protocol was established as a standard non- anthracycline protocol for older and cardiovascular patients. Excellent results were obtained in the treatment of small Her2 positive tumors with a combination of taxane and targeted therapy, without previous anthracycline chemotherapy. An advantage of the dose-dense application regimens has been demonstrated over the standard three-week-apart applications.

From the first confirmation of the role of taxanes to date, there were no revolutionary innovations or changes in the adjuvant treatment of breast cancer, but the progress in optimizing the dose and regimen of administration is evident. Significant improvement in rate of complete pathological responses and DFS was reported in neoadjuvant treatment with nab-paclitaxel (nanoparticle albumin-bound paclitaxel) in comparison with conventional paclitaxel (35). Further investigations with this form of drug in adjuvant setting are ongoing.

Today, the most important global oncology associations, the American National Comprehensive Cancer Network (NCCN) and the European Society for Medical Oncology (ESMO) clearly point out the role of taxanes added to anthracycline chemotherapy in total reduction of mortality risk by $1 / 3$ and in improving adjuvant breast cancer treatment, with less pronounced cardiac toxicity. They recommend the sequential administration of taxanes after anthracycline regimen and the use of weekly paclitaxel and three-weekly docetaxel as the best choice.

Issues that remain open for future discussion are numerous indications for off label use of taxane therapy, which could serve as a model for new 
opportunities in the use of these drugs, the issue of treatment duration in metastatic disease and management of side effects, the issue of combination of taxanes with other cytotoxic drugs and targeted therapies, as well as the issue of new formulations of these drugs.

\section{LITERATURE:}

1. Early Breast Cancer Trialists' Collaborative Group (EBCTCG). Effects of chemotherapy and hormonal therapy for early breast cancer on recurrence and 15year survival: an overview of the randomised trials. Lancet. 2005 May 14-20;365(9472):1687-717.

2. Volkova M, Russell R. Anthracycline Cardiotoxicity: Prevalence, Pathogenesis and Treatment. Curr Cardiol Rev. 2011 Nov;7(4):214-220.

3. Močilac P. Povijesni razvoj farmakološkog liječenja zloćudnih bolesti. Farmaceutski glasnik 2008;64(4):179199.

4. Pazdur R, Kudelka AP, Kavanagh JJ, Cohen PR, Raber MN. The taxoids: paclitaxel (Taxol) and docetaxel (Taxotere). Cancer Treat Rev. 1993 Oct;19(4):351-86.

5. Rowinsky EK. The development and clinical utility of the taxane class of antimicrotubule chemotherapy agents. Annu Rev Med. 1997;48:353-74.

6. Hall E, Cameron D, Waters R, Barrett-Lee P, Ellis P, Russell $\mathrm{S}$ et al. Comparison of patient reported quality of life and impact of treatment side effects experienced with a taxane-containing regimen and standard anthracycline based chemotherapy for early breast cancer: 6 year results from the UK TACT trial (CRUK/01/001). Eur J Cancer. 2014 Sep;50(14):2375-89.

7. Nabholtz JM, Gelmon K, Bontenbal M, Spielmann M, Catimel G, Conte P et al. Multicenter, randomized comparative study of two doses of paclitaxel in patients with metastatic breast cancer. J Clin Oncol. 1996 Jun;14(6):1858-67.

8. Sartor CI, Peterson BL, Woolf S, Fitzgerald TJ, Laurie $\mathrm{F}$, Turrisi AJ et al. Effect of addition of adjuvant paclitaxel on radiotherapy delivery and locoregional control of node-positive breast cancer: cancer and leukemia group B 9344. J Clin Oncol 23(1):30-40.

9. Mamounas EP, Bryant J, Lembersky B, Fehrenbacher L, Sedlacek SM, Fisher B et al. Paclitaxel After Doxorubicin Plus Cyclophosphamide As Adjuvant Chemotherapy for Node-Positive Breast Cancer: Results From NSABP B-28. J Clin Oncol. 2005 Jun 1;23(16):3686-96.

10. Roché $\mathrm{H}$, Fumoleau $\mathrm{P}$, Spielmann $\mathrm{M}$, Canon JL, Delozier T, Serin D et al. Sequential adjuvant epirubicinbased and docetaxel chemotherapy for node-positive breast cancer patients: the FNCLCC PACS 01 Trial. J Clin Oncol. 2006 Dec 20;24(36):5664-71.

11. Martín M, Rodríguez-Lescure A, Ruiz A, Alba E, Calvo L, Ruiz-Borrego M et al. Randomized phase 3 trial of fluorouracil, epirubicin, and cyclophosphamide alone or followed by Paclitaxel for early breast cancer. J Natl Cancer Inst. 2008 Jun 4;100(11):805-14.

12. Buzdar AU, Singletary SE, Valero V, Booser DJ, Ibrahim NK, Rahman Z et al. Evaluation of paclitaxel in adjuvant chemotherapy for patients with operable breast cancer: preliminary data of a prospective randomized trial. Clin Cancer Res. 2002 May;8(5):1073-9.

13. Ellis $\mathrm{P}$, Barrett-Lee $\mathrm{P}$, Johnson L, Cameron $\mathrm{D}$, Wardley A, O'Reilly S, Verrill M et al. Sequential docetaxel as adjuvant chemotherapy for early breast cancer (TACT): an open-label, phase III, randomised controlled trial. Lancet. 2009 May 16;373(9676):1681-92.

14. Albert JM, Buzdar AU, Guzman R, Allen PK, Strom EA, Perkins GH et al. Prospective randomized trial of 5-fluorouracil, doxorubicin, and cyclophosphamide (FAC) versus paclitaxel and FAC (TFAC) in patients with operable breast cancer: impact of taxane chemotherapy on locoregional control. Breast Cancer Res Treat. 2011 Jul;128(2):421-427.

15. Martin M, Pienkowski T, Mackey J, Pawlicki M, Guastalla JP, Weaver C et al. Breast Cancer International Research Group 001 Investigators. Adjuvant docetaxel for node-positive breast cancer. N Engl J Med. 2005 Jun 2;352(22):2302-13.

16. Mackey JR, Martin M, Pienkowski T, Rolski J, Guastalla JP, Sami A et al. Adjuvant docetaxel, doxorubicin, and cyclophosphamide in node-positive breast cancer: 10-year follow-up of the phase 3 randomised BCIRG 001 trial. Lancet Oncol. 2013 Jan;14(1):72-80.

17. Goldstein LJ, O'Neill A, Sparano JA, Perez EA, Shulman LN, Martino S et al. Concurrent Doxorubicin Plus Docetaxel Is Not More Effective Than Concurrent Doxorubicin Plus Cyclophosphamide in Operable Breast Cancer With 0 to 3 Positive Axillary Nodes: North American Breast Cancer Intergroup Trial E 2197. J Clin Oncol. 2008 Sep 1;26(25):4092-4099.

18. Crozier JA, Swaika A, Moreno-Aspitia A. Adjuvant chemotherapy in breast cancer: To use or not to use, the anthracyclines. World J Clin Oncol. 2014 Aug 10; 5(3):529-538.

19. Martín M, Seguí MA, Antón A, Ruiz A, Ramos M, Adrover $\mathrm{E}$ et al. Adjuvant docetaxel for high-risk, node-negative breast cancer. N Engl J Med. 2010 Dec 2;363(23):2200-10.

20. Ferguson T, Wilcken N, Vagg R, Ghersi D, Nowak AK. Taxanes for adjuvant treatment of early breast cancer. Cochrane DatabaseSystRev. 2007 Oct 17;(4):CD004421.

21. Early Breast Cancer Trialists' Collaborative Group (EBCTCG). Comparisons between different polychemotherapy regimens for early breast cancer: metaanalyses of long-term outcome among 100,000 women in 123 randomised trials. Lancet. 2012 Feb 4;379(9814):432-44.

22. Citron ML, Berry DA, Cirrincione C, Hudis C, Winer EP, Gradishar WJ et al. Randomized trial of dosedense versus conventionally scheduled and sequential versus concurrent combination chemotherapy as post- 
operative adjuvant treatment of node-positive primary breast cancer: first report of Intergroup Trial C9741/ Cancer and Leukemia Group B Trial 9741. J Clin Oncol. 2003 Apr 15;21(8):1431-9.

23. Sonnenblick A, Francis PA, Azim HA Jr, de Azambuja E, Nordenskjöld B, Gutiérez J et al. Final 10-year results of the Breast International Group 2-98 phase III trial and the role of Ki67 in predicting benefit of adjuvant docetaxel in patients with oestrogen receptor positive breast cancer. Eur J Cancer. 2015 Aug;51(12):1481-9.

24. Shulman LN, Cirrincione CT, Berry DA, Becker HP, Perez EA, O'Regan R et al. Six Cycles of Doxorubicin and Cyclophosphamide or Paclitaxel Are Not Superior to Four Cycles As Adjuvant Chemotherapy for Breast Cancer in Women With Zero to Three Positive Axillary Nodes: Cancer and Leukemia Group B 40101. J Clin Oncol. 2012 Nov 20; 30(33): 4071-4076.

25. Sparano JA, Zhao F, Martino S, Ligibel JA, Perez EA, Saphner T et al. Long-Term Follow-Up of the E1199 Phase III Trial Evaluating the Role of Taxane and Schedule in Operable Breast Cancer. J Clin Oncol. 2015 Jul 20;33(21):2353-60.

26. Budd GT, Barlow WE, Moore HC, Hobday TJ, Stewart JA, Isaacs C et al. SWOG S0221: a phase III trial comparing chemotherapy schedules in high-risk early-stage breast cancer. J Clin Oncol. 2015 Jan 1;33(1):58-64.

27. Burkard ME, Wisinski KB, Njiaju UO, Donohue S, Hegeman R, Stella A et al. Feasibility of 4 cycles of docetaxel and cyclophosphamide every 14 days as an adjuvant regimen for breast cancer: a Wisconsin Oncology Network study. Clin Breast Cancer. 2014 Jun;14(3):205-11.

28. Mavroudis D, Matikas A, Malamos N, Papakotoulas P, Kakolyris S, Boukovinas I et al. Dose-dense FEC followed by docetaxel versus docetaxel plus cyclophosphamide as adjuvant chemotherapy in women with HER2-negative, axillary lymph node-positive early breast cancer: a multicenter randomized study by the Hellenic Oncology Research Group (HORG). Ann Oncol. 2016 Oct;27(10):1873-8.

29. Cameron D, Piccart-Gebhart MJ, Gelber RD, Procter M, Goldhirsch A, de Azambuja E et al. 11 years' follow-up of trastuzumab after adjuvant chemotherapy in HER2-positive early breast cancer: final analysis of the HERceptin Adjuvant (HERA) trial. Lancet. 2017 Mar 25;389(10075):1195-1205.

30. Tan-Chiu E, Yothers G, Romond E, Geyer CE Jr, Ewer $\mathrm{M}$, Keefe D et al. Assessment of cardiac dysfunction in a randomized trial comparing doxorubicin and cyclophosphamide followed by paclitaxel, with or without trastuzumab as adjuvant therapy in node-positive, human epidermal growth factor receptor 2-overexpressing breast cancer: NSABP B-31. J Clin Oncol. 2005 Nov 1;23(31):7811-9.

31. Perez EA, Romond EH, Suman VJ, Jeong JH, Davidson NE, Geyer CE Jr et al. Four-year follow-up of trastuzumab plus adjuvant chemotherapy for operable human epidermal growth factor receptor 2-positive breast cancer: joint analysis of data from NCCTG N9831 and NSABP B-31. J Clin Oncol. 2011 Sep 1;29(25):3366-73.

32. Tolaney SM, Barry WT, Dang CT, Yardley DA, Moy B, Marcom PK et al. Adjuvant paclitaxel and trastuzumab for node-negative, HER2-positive breast cancer. N Engl J Med. 2015 Jan 8;372(2):134-41.

33. Jones SE, Collea R, Paul D, Sedlacek S, Favret AM, Gore I Jr et al. Adjuvant docetaxel and cyclophosphamide plus trastuzumab in patients with HER2-amplified early stage breast cancer: a single-group, openlabel, phase 2 study. Lancet Oncol. 2013 Oct;14(11):1121-8.

34. Perez EA, Suman VJ, Davidson NE, Gralow JR, Kaufman PA, Visscher DW et al. Sequential versus concurrent trastuzumab in adjuvant chemotherapy for breast cancer. J Clin Oncol. 2011 Dec 1;29(34):4491-7.

35. Untch M, Jackisch C, Schneeweiss A, Conrad B, Aktas B, Denkert C et al. Nab-paclitaxel versus solventbased paclitaxel in neoadjuvant chemotherapy for early breast cancer (GeparSepto-GBG 69): a randomised, phase 3 trial. Lancet Oncol. 2016 Mar;17(3):345-56.

Corresponding author: Ana Tečić-Vuger, Department of Radiotherapy and Medical Oncology, University Hospital for Tumors, Sestre milosrdnice University Hospital Center, Ilica 197, 10000 Zagreb,Croatia.e-mail: ana.tecic@ yahoo.com 